\title{
Evolving Resolve
}

Walter Veit ${ }^{1} \&$ David Spurrett ${ }^{2}$

\begin{abstract}
:
The broad spectrum revolution brought greater dependence on skill and knowledge, and more demanding, often social, choices. We adopt Sterelny's account of how cooperative foraging paid the costs associated with longer dependency, and transformed the problem of skill learning. Scaffolded learning can facilitate cognitive control including suppression, while scaffolded exchange and trade, including intertemporal exchange, can help develop resolve.
\end{abstract}

Please cite as: Veit, W. \& Spurrett, D. (forthcoming). Evolving Resolve. Behavioral and Brain Sciences.

The Neolithic Revolution (the transition from hunter-gatherer lifestyle to agriculture) was preceded by the 'Broad Spectrum Revolution' in the Upper Paleolithic (Flannery 1969). This saw increasing reliance on a wider variety of food sources, including ones requiring skilled processing and more sophisticated technology (Stiner 2001). Broad spectrum hunting and gathering required skills and knowledge that no lone individual could have accumulated from scratch, and which varied quickly enough to outpace genetic selection.

We adopt Sterelny's (2012) argument that expansion in hominin expertise and reliance on technology was driven by feedback loops linking co-operative foraging, learning, and transformation of the environment. Learning broad-spectrum foraging is time-consuming and expensive, but cooperative foraging provides enough surplus to support itself. Culturally transmitted skill learning is facilitated by a transformation of the learning environment, in addition - eventually - to master-apprentice relationships. This framework can be put to work addressing the evolution of suppression and resolve, complementing Ainslie's (2020) suggestions in the target article.

Ainslie correctly notes that the evolution of the influence of future expectations on current preference is itself a resource for sophisticated tool use and other distinctive hominin practices. Advanced tool making, tool use, food preservation and storage, exploitation of food requiring processing, and group hunting require foresight and often demand extended current effort with high costs and delayed returns. Acquiring the skills for broad spectrum life takes time, perhaps many years, before an individual generates a surplus (King 1991). Hominin life, that is, depends on extended and repeated intergenerational transfer of support and skill.

\footnotetext{
${ }^{1}$ wrwveit@gmail.com; University of Sydney; https://walterveit.com/

2 spurrett@ukzn.ac.za; University of KwaZulu-Natal
} 
Execution of a skill like stone knapping depends on socially acquired cognitive control models (Christensen et al 2016, Hiscock 2014, Shipton 2010). These involve hierarchically and temporally organised goals, and their application demands attention management. Sterelny (2012) argues that small motivational changes, including increased tolerance for unrelated young watching and imitating, and increased interest in adult activities by the young, can improve the fidelity of trial and error learning. Without tolerance, interest in adults is punished. With it, it is rewarded. He also stresses how the acquisition of expertise can be supported by the learning environment. For example, learning tool-making is facilitated by having the stages from material selection performed openly, with samples from the stages of manufacture available for inspection, play, and imitation.

Maintaining focus on task goals and sub-goals in the face of distractions and incomplete recall demands what Ainslie calls suppression. This challenge is reduced when the environment provides scaffolding in the form of models and reminders of goals, sequencing and methods. Supervision helps even more. Years of experience might be needed before achieving relative independence from those props. Developing individual skill at suppression, that is, needn't be an unaided individual achievement. Co-operative foraging can both scaffold learning it, and pay for the time it takes.

Increasing intra-group specialisation, a wider variety of foraging targets and a larger portfolio of tools and technology brings increasing reliance on exchange across more and varying modalities organised over much longer time-scales for hominins than other animals. Tools and other artefacts, shares of hunts and processed vegetables, child-care, protection and much more had to be allocated and sometimes exchanged. Those who made exchanges that were too inconsistent with their longer run interests would have done badly.

Economists since Smith (1776) have favoured the idea that money arose to address inefficiencies in barter-based systems of simultaneous exchange, making delayed repayment possible. This myth is rejected by all available evidence. In societies without token money barter is either absent, restricted, or occurs between non-relatives and whole groups, and exchange, including gift, involving credit and later repayment is ubiquitous within groups (Graeber 2011, Chapman 1980). Much later, token money appears to have transformed practices of valuation and exchange, but this won't illuminate Paleolithic agency.

Features of later societies provide clues. Morgan (1851) explained how surplus in Iroquois nations was stored in longhouses, and distribution handled by councils of women. Meggitt (1971) detailed a conventional hierarchy of gift-types specifying acceptable reciprocation (a stone axe could discharge a debt of a pork side, but not a whole pig), and Lévi-Strauss (1949) how rules among the Tsonga specified the division of a whole ox among a group of relatives receiving one (front leg to elder brother, hind leg to younger, etc.). Khan (19860) documents an intertemporal mechanism among the Wamira: a gift of a female pig obliged repayment with that very pig's female offspring, and required shouting at the time of transfer to specify whether debt was being created or settled. Loud complaining about disappointing reciprocation is widely documented (e.g. Marlowe 2010). Between-group barter often involved conventions, such as that one cow was worth 50 baskets of rice among the Naga of India (Einzig 1949). Such socially 
stabilised practices simplify exchanges by constraining the options and crowd-sourcing the burden of tracking obligations, including delayed ones.

Exchanging and sharing in the open would also provide opportunities for learning, and allow for stabilising input from others, including reminders of delayed consequences. Apprentice learning, when it took off, likely involved supervision in exchange along with execution and assessment of quality. Even without supervision proper, seniors ridiculing or approving a nascent exchange could provide learning signals and scaffold consistency. Gossip, when available, could distribute recognition of the easily exploitable or notably astute. Repeated and open inter-temporal bargaining and cooperation among group members can thus increase consistency and scaffold precursors to resolve. Like stone-knapping which develops in a cognitive niche including successful practitioners and their products, resolve can begin socially in a shared consumption scheduling niche. Here too, the surplus generated by mature members is crucial. No hominin could acquire the skill for cooperative foraging without the surplus and learning environment generated by a group succeeding at it. The skill of temporally organised choice called resolve is arguably no different.

\section{References}

Ainslie, G. (2020). Willpower With and Without Effort. Behavioral and Brain Sciences, 1-81. doi:10.1017/S0140525X20000357

Chapman, A. (1980) Barter as a Universal Mode of Exchange. L'Homme 22 (3): 33-83.

Christensen, W., Sutton, J. \& McIlwain, D.J.F. (2016) Cognition in Skilled Action: Meshed Control and the Varieties of Skill Experience. Mind and Language 31(1): 37-66.

Einzig, P. (1949) Primitive Money in Its Ethnological, Historical and Economic Aspects. Eyre \& Spottiswoode.

Flannery, K. (1969) Origins and Ecological Effects of Early Domestication in Iran and the Near East. In: The Domestication and Exploitation of Plants and Animals, ed. P. J. Ucko \& G.W. Dimbleby, pp. 73-100, Aldine Publishing Co.

Graeber, D. (2011) Debt: The First 5,000 Years., NY: Melville House.

Hiscock, P. (2014) Learning in Lithic Landscapes: A Reconsideration of the Hominid "Toolmaking" Niche. Biological Theory 9: 27-41.

Kahn, M. (1986) Always Hungry, Never Greedy: Food and the Expression of Gender in a Melanesian Society. Cambridge.

King, B. J. (1991) Social information transfer in monkeys, apes, and hominids. American Journal of Physical Anthropology 34(S13): 97-115. 
Marlowe, F. W. (2010). The Hadza: Hunter-Gatherers of Tanzania. Berkeley, University of California Press.

Meggitt, M.J. (1971) From Tribesmen to Peasants: The Case of the Mae-Enga of New Guinea. In: Anthropology in Oceania, ed. L.R. Hiatt \& C.J. Jayawardena, pp. 191-209, Angus and Robertson.

Morgan, H.L. (1851) The League of the Ho-dé-no-sau-nee or Iroquois. Sage and Brothers.

Shipton, C. (2010) Imitation and Shared Intentionality in the Acheulean. Cambridge Archaeological Journal 27(2): 197-210.

Smith, A. (1776) An Inquiry into the Nature and Causes of the Wealth of Nations, W. Strahan.

Sterelny, K. (2012) The Evolved Apprentice. MIT.

Stiner, M. C. (2001). Thirty years on the "Broad Spectrum Revolution" and paleolithic demography. Proceedings of the National Academy of Sciences, 98(13): 6993-6996. 